\title{
Pertimbangan Hakim Dalam Menjatuhkan Putusan Denda Bersifat Minimum Khusus Dalam Delik Narkotika
}

\author{
Heri Zuniarto \\ Fakultas Hukum Universitas Islam Indonesia Yogyakarta Indonesia \\ Jln. Cik Di Tiro No. 1, Yogyakarta, Indonesia 55223 \\ zuniartohery@gmail.com
}

\begin{abstract}
The eradication of criminal acts of narcotics has been carried out through a judicial process with the regulation of Law Number 35 of 2009 on Narcotics as a guideline for law enforcement. However, in practice, there are still problems, especially for judges in considering a fine sentence which is regulated specifically with a high enough limit. This study aims to determine the judges' considerations in imposing a fair decision against a special minimum fine in narcotics crime. The research method used is normative-empirical based on statutory law material adjusted to the facts of its application in the judiciary, with juridical normative and empirical juridical approaches. The results of the research found that the special minimum provisions for fine sentences that were quite high were an obstacle for judges in considering the amount of fines to be imposed on the defendant, so that judges tended to impose the amount of fines according to the specific minimum limit of fines, although in implementing the verdict the convict preferred to serve imprisonment as an alternative to fines that cannot be paid. This phenomenon makes the application of fines in judges' decisions inefficient, especially in the absence of regulations in the Narcotics Law regarding coercion in the context of the application of the penalty itself.
\end{abstract}

Key Words: Fine sentences; inefficient; judge's consideration; special minumum

\begin{abstract}
Abstrak
Pemberantasan tindak pidana narkotika telah dilaksanakan melalui proses peradilan dengan regulasi Undang-Undang Nomor 35 Tahun 2009 tentang Narkotika sebagai pedoman penegakkan hukumnya. Namun, dalam praktiknya masih terdapat permasalahan, terutama bagi hakim dalam mempertimbangkan putusan pidana denda yang diatur secara minimum khusus dengan batasan yang cukup tinggi. Penelitian ini bertujuan untuk mengetahui pertimbangan hakim dalam menjatuhkan putusan yang berkeadilan terhadap pidana denda yang bersifat minimum khusus dalam tindak pidana narkotika. Metode penelitian yang digunakan adalah normatif-empiris yang bersumber pada bahan hukum perundang-undangan disesuaikan dengan fakta penerapannya dalam peradilan, dengan pendekatan yuridis normatif dan yuridis empiris. Hasil dari penelitian menyimpulkan bahwa ketentuan minimum khusus pidana denda yang cukup tinggi menjadi kendala bagi hakim dalam mempertimbangkan besaran denda yang akan dijatuhkan terhadap terdakwa, sehingga hakim cenderung menjatuhkan besaran denda sesuai batas minimum khusus denda, meskipun dalam pelaksanaan putusan terpidana lebih memilih untuk menjalani pidana penjara sebagai alternatif pidana denda yang tidak mampu dibayar. Fenomena ini menjadikan penerapan pidana denda dalam putusan hakim menjadi tidak efisien, apalagi dengan tidak adanya aturan dalam Undang-Undang Narkotika mengenai upaya paksa dalam rangka penerapan pidana denda itu sendiri.
\end{abstract}

Kata-kata kunci: Minimum khusus; pertimbangan hakim; pidana denda; tidak efisien 


\section{Pendahuluan}

Lembaga peradilan sebagai suatu tempat untuk mencari keadilan bagi setiap warga negara diharapkan dapat memenuhi rasa keadilan dalam masyarakat. Hakim sebagai elemen terpenting dalam lembaga peradilan mempunyai peranan yang sangat besar dalam memberikan suatu putusan yang berkeadilan, utamanya terhadap setiap orang yang berperkara di persidangan. Suatu putusan pengadilan yang mempunyai nilai keadilan bagi semua pihak, tentunya tidak terlepas dari suatu sistem peradilan pidana yang mana sub sistem atau komponen-komponennya berjalan dengan baik. Komponen sistem peradilan pidana yang lazim diakui, baik dalam pengetahuan mengenai kebijakan kriminal (criminal policy) maupun dalam praktik penegakan hukum, terdiri atas unsur kepolisian, kejaksaan, pengadilan, dan lembaga pemasyarakatan. ${ }^{1}$ Komponen sistem peradilan pidana dalam pelaksanaan fungsinya pada perkembangannya saat ini dinilai masih belum maksimal yang pada akhirnya bermuara pada suatu putusan pengadilan yang dirasa belum memenuhi rasa keadilan bagi para pihak yang berperkara.

Sistem peradilan pidana merupakan suatu jaringan (network) peradilan yang menggunakan hukum pidana sebagai sarana utamanya, baik hukum pidana materiil, hukum pidana formil maupun hukum pelaksanaan pidana. Namun demikian kelembagaan substansial ini harus dilihat dalam kerangka atau konteks sosial. Sifatnya yang terlalu formal apabila dilandasi hanya untuk kepentingan kepastian hukum saja akan membawa kepada ketidakadilan. ${ }^{2}$ Secara sederhana sistem paradilan pidana dapat dipahami sebagai suatu usaha untuk menjawab apa tugas hukum pidana di masyarakat dan bukan sekedar bagaimana hukum pidana di dalam undang-undang dan bagaimana hakim menerapkannya. Sebagai suatu sistem maka di dalam pelaksanaannya terdapat suatu syarat yang wajib dipenuhi berupa kerjasama di antara sub sistem atau komponen, dengan demikian tidak berjalannya salah satu sub sistem sebagaimana mestinya, maka akan mengganggu sistem secara keseluruhan, sehingga keempat sub sistem tersebut memiliki hubungan yang erat satu dengan yang lainnya.

Kejaksaan sebagai bagian dari sub sistem peradilan pidana dengan penuntut umumnya berada pada sisi subyektif yang dalam melaksanakan penuntutan dilakukan secara obyektif, disisi lain harus dilakukan dengan mencerminkan keadilan bagi semua pihak. Demikian pula posisi hakim dalam mengadili suatu perkara tentunya harus dilakukan secara bebas dan independen, namun

1 Romli Atmasasmita, Sistem Peradilan Pidana (Criminal Justice System) Perspektif Eksistensialisme Dan Abolisionalisme, Bina Cipta, Jakarta, 1996, hlm. 24.

${ }^{2}$ Yogi Indra, "Pengertian Sistem Peradilan Pidana Menurut Para Ahli Beserta Unsur-Unsurnya", https://www.academia.edu/36002666/PENGERTIAN_SISTEM_PERADILAN_PIDANA_MENURUT_ PARA AHLI BESERTA UNSUR-UNSURNYA, diakses tanggal 28 Februari 2020. 
demikian baik penuntut umum maupun hakim dalam melaksanakan perannya masing-masing tentunya harus memperhatikan pula perkembangan efisiennya penerapan suatu pidana baik yang dituntutkan kepada subyek hukum yang terbukti melakukan suatu tindak pidana yang didakwakan pada sisi penuntut umum, maupun suatu putusan pada posisi hakim dalam menjatuhkan putusan pidana. Ada kecenderungan besar pada para penegak hukum untuk menafsirkan ketentuan perundang-undangan, secara dogmatis belaka. Penafsiran secara sosiologis, misalnya, seringkali hanya merupakan pengecualian. Memang, mungkin hal ini merupakan salah satu akibat dari adanya persepsi dari kalangan atas, bahwa hukum hanyalah perundang-undangan saja. Akibatnya adalah terjadinya "disiplin" yang kaku dalam penafsiran perundang-undangan. ${ }^{3}$ Dalam praktek peradilan pidana bukan hanya dari sisi sub sistemnya saja yang yang menjadi faktor penentu suatu penegakan hukum bernilai keadilan, akan tetapi peraturan perundang-undangan sebagai pedoman dalam menentukan pidana yang akan diterapkan juga memberikan andil dalam proses penegakan hukum yang berkeadilan. Beberapa peraturan perundang-undangan pidana di luar Kitab Undang-Undang Hukum Pidana yang berlaku saat ini dalam perkembangannya masih terdapat ketentuan-ketentuan yang tidak sepenuhnya dapat dilaksanakan secara efisien sebagaimana tujuan dari dibentuknya undang-undang itu sendiri yang dalam permasalahan ini antara lain mengenai sudut pandang hakim dalam menentukan besaran nilai pidana kumulatif denda yang diatur secara minimum khusus terhadap subyek hukum yang dinyatakan terbukti bersalah melakukan tindak pidana Narkotika.

Undang-Undang Republik Indonesia Nomor 35 Tahun 2009 tentang Narkotika merupakan salah satu ketentuan pidana diluar Kitab Undang-Undang Hukum Pidana yang secara eksplisit mengatur pidana penjara dan denda untuk dijatuhkan secara bersamaan dalam suatu putusan hakim, sejalan dengan pidana yang bersifat kumulatif. Pengaturan yang demikian dalam Undang-Undang Republik Indonesia Nomor 35 Tahun 2009 dikarenakan bobot perbuatannya yang dinilai membahayakan kepentingan masyarakat, bahkan mungkin dianggap merugikan Negara. Undang-Undang Republik Indonesia Nomor 35 Tahun 2009 sebagai Lex Spesialis mengatur ancaman pidana penjara dan denda secara kumulatif. Beberapa pasal didalam Undang-Undang Republik Indonesia Nomor 35 Tahun 2009 tentang Narkotika menerapkan pidana denda yang diatur secara kumulatif dengan pidana penjara yang besaran nilainya ditetapkan bervariatif

${ }^{3}$ Panda Nababan dan R. M. Suripto (Penyunting Diskusi Pemikir Hukum Indonesia), Menangkap Rasa Keadilan Masyarakat oleh Penegak Hukum, Cetakan I, Yayasan Keadilan, Jakarta, 1988, hlm. 33. 
dengan pembatasan minimum. Pengaturan pidana kumulatif antara pidana penjara dan denda dengan batasan minimum tersebut diklasifikasikan dalam Pasal 111, Pasal 112, Pasal 113, Pasal 114, Pasal 115, Pasal 116, Pasal 117, Pasal 118, Pasal 119, Pasal 120, Pasal 121, Pasal 123, Pasal 124, 125, dan Pasal 126.

Pidana denda dalam Undang-Undang Nomor 35 Tahun 2009 berbeda pengaturannya dengan Kitab Undang-Undang Hukum Pidana (KUHP). Pidana penjara dan denda sebagaimana diatur dalam Pasal 10 Kitab Undang-Undang Hukum Pidana merupakan 2 jenis pidana yang berbeda, tetapi keduanya termasuk dalam pidana pokok. Pidana penjara sebagai hukuman badan, sedangkan hukuman denda sebagai hukuman pembayaran sejumlah uang yang apabila tidak dibayar dapat diganti dengan pidana kurungan paling singkat satu hari dan paling lama enam bulan sebagaimana bunyi ketentuan Pasal 30 ayat (2) KUHP. ${ }^{4}$ Pidana penjara maupun denda hanya dapat dijatuhkan salah satu saja oleh hakim dalam putusannya.

Pengaturan pidana yang bersifat kumulatif antara penjara dan denda dalam Undang-Undang Nomor 35 Tahun 2009 tentang Narkotika, mewajibkan penuntut umum menerapkannya dalam suatu surat tuntutannya, demikian pula majelis hakim dalam putusannya. Majelis hakim dalam kapasitas mengadili akan dihadapkan dengan permasalahan mengenai penentuan besaran nilai denda yang akan dijatuhkan, oleh karena Undang-Undang Nomor 35 Tahun 2009 tentang Narkotika sendiri tidak memberikan pedoman secara jelas bagaimana menilai besaran pidana denda yang akan dijatuhkan kepada terdakwa sesuai porsinya baik dari sisi bobot perbuatan yang dilakukan terdakwa atau kemampuan finansial yang dipandang mampu bagi terdakwa untuk membayar denda yang akan dijatuhkan, terlebih kecil kemungkinan hakim menyimpangi ketentuan perundang-undangan dengan menjatuhkan pidana denda dibawah batas minimum, sehingga akan berpengaruh pada penilaian rasa keadilan atas putusan tersebut, bahkan dapat berdampak pula pada perbedaan pandangan masing-masing hakim dalam menjatuhkan pidana denda dengan perkara yang lain. Permasalahan selanjutnya dengan adanya perbedaan pandangan dalam penjatuhan hukuman denda tersebut adalah adanya suatu disparitas antara putusan yang satu dengan putusan yang lain.

Penjatuhan pidana denda tidak dapat dilepaskan begitu saja tanpa melihat kemampuan terdakwa untuk membayar denda yang akan dijatuhkan dalam suatu putusan, terlebih dalam Undang-Undang Nomor 35 Tahun 2009 tentang Narkotika telah diatur secara jelas mengenai batasan minimum hukuman denda yang harus dijatuhkan. Permasalahan berikutnya yang mungkin timbul adalah apakah suatu

${ }^{4}$ Moeljatno, Kitab Undang-Undang Hukum Pidana, Cetakan Keduapuluh Tujuh, Bumi Aksara, Jakarta, 2008, hlm. 16 . 
putusan telah memenuhi rasa keadilan terhadap seorang terdakwa yang dijatuhi hukuman denda melebihi kemampuannya untuk membayar pidana denda tersebut, meskipun pidana denda tersebut dapat diganti dengan menjalani penjara apabila tidak mampu membayar sebagaimana ketentuan Pasal 148 Undang-Undang Republik Indonesia Nomor 35 Tahun 2009 tentang Narkotika yang berbunyi "Apabila putusan pidana denda sebagaimana diatur dalam Undang-Undang ini tidak dibayar oleh pelaku tindak pidana Narkotika dan tindak pidana Presekusor Narkotika, pelaku dijatuhi pidana penjara paling lama 2 (dua) tahun sebagai pengganti denda yang tidak dapat dibayar"5, sehingga memunculkan kembali suatu permasalahan hukum tentang efisienkah penjatuhan pidana denda atas putusan yang dijatuhkan oleh hakim. Menurut J. Andenaes dalam teori perlindungan masyarakat (the theory of social defense), memidana bukanlah untuk memuaskan tuntutan absolut keadilan. Pembalasan itu sendiri tidak mempunyai nilai, tetapi hanya sebagai sarana untuk melindungi kepentingan masyarakat. ${ }^{6}$

Dari uraian di atas, tentu muncul sebuah dilema bagi hakim dalam menjatuhkan suatu putusan atas pelaku tindak pidana narkotika yang ketentuan pidananya telah diatur secara kumulatif dengan batasan minimum khusus maupun penuntut umum sebagai eksekutor atas putusan hakim, di sisi lain harapan masyarakat terhadap suatu putusan pengadilan yang dihasilkan mempunyai nilai keadilan dalam masyarakat, dan tidak berujung pada suatu putusan yang sia-sia dalam pelaksanaanya.

Berdasarkan informasi data yang dirangkum dalam latar belakang masalah ini, penulis bermaksud menganalisis pertimbangan hakim dalam menjatuhkan putusan pidana denda yang bersifat minimum khusus dalam delik narkotika.

\section{Rumusan Masalah}

Sehubungan dengan uraian dalam latar belakang masalah di atas, maka permasalahan yang dirumuskan dalam penulisan ini adalah bagaimana pertimbangan hakim dalam menjatuhkan putusan terhadap pidana denda yang bersifat kumulatif dengan pembatasan minimum dalam tindak pidana narkotika?

\section{Tujuan Penelitian}

Berdasarkan permasalahan tersebut di atas, maka tujuan dari penelitian ini untuk mengetahui dasar pertimbangan hakim dalam menjatuhkan putusan

\footnotetext{
${ }^{5}$ Undang-Undang Republik Indonesia Nomor 35 Tahun 2009 tentang Narkotika.

${ }^{6}$ Mohammad Taofik Makarao, Pembaharuan Hukum Pidana Indonesia, Cetakan Pertama, Kreasi Wacana, Yogyakarta, 2005, hlm. 44.
} 
pidana denda yang sifatnya kumulatif dengan pembatasan minimum khusus terhadap subjek hukum yang terbukti bersalah melakukan tindak pidana narkotika sebagai wujud suatu putusan yang berkeadilan, yaitu mengenai penafsiran hakim terhadap sanksi pidana berbentuk kumulatif-minimum khusus dan penilaian hakim terhadap keadaan sosial ekonomi seorang terdakwa sebagai subjek hukum untuk melakukan pembayaran atas pidana denda yang akan dijatuhkan dalam putusan.

\section{Metode Penelitian}

Pada prinsipnya, inti dari metodologi setiap penelitian hukum adalah menguraikan tentang tata cara bagaimana suatu penelitian hukum itu harus dilakukan. ${ }^{7}$ Mengingat permasalahan dalam penelitian ini difokuskan pada penerapan pidana denda yang bersifat kumulatif-minimum khusus dalam Undang-Undang Republik Indonesia Nomor 35 Tahun 2009 tentang Narkotika dalam suatu putusan hakim, khususnya terhadap beberapa pasal yang mengatur pidana denda dengan pembatasan minimum, maka pendekatan yang dilakukan adalah pendekatan Yuridis Normatif. Namun untuk menunjang penelitian ini, dilakukan pendekatan Yuridis Empiris. Pendekatan Yuridis Empiris diperlukan untuk mengetahui gambaran penerapan putusan pidana denda yang bersifat kumulatif dengan pembatasan minimum di dalam praktek pengadilan. Penelitian ini menggunakan data sekunder sebagai data awal kemudian dilanjutkan dengan data primer atau data lapangan.

\section{Hasil Penelitian dan Pembahasan}

\section{Pertimbangan Hakim dalam Menjatuhkan Putusan Pidana Denda Tindak Pidana Narkotika}

Undang-Undang Nomor 35 Tahun 2009 tentang Narkotika merupakan dasar hukum penegakan hukum pidana dalam rangka pemberantasan dan penanggulangan kejahatan narkotika di Indonesia. Penegakan hukum terhadap tindak pidana narkotika telah dilakukan oleh penegak hukum mulai dari tindakan penyidikan, penuntutan hingga proses persidangan yang bermuara pada suatu putusan pengadilan. Namun dalam suatu proses peradilan bukan tidak mungkin terdapat suatu kendala. Dalam hal ini terkait penegakan hukum dalam rangka pemberantasan penyalahgunaan dan peredaran gelap narkotika. Salah satu kendala tersebut dalam hal putusan hakim terkait pidana pokok denda yang diatur secara minimum khusus.

\footnotetext{
${ }^{7}$ Bambang Waluyo, Penelitian Hukum Dalam Praktek, Sinar Grafika, Jakarta, 1996, hlm. 17.
} 
Beberapa pasal dalam Undang-Undang Nomor 35 Tahun 2009 tentang Narkotika mengatur mengenai sanksi pidana pokok antara penjara dan denda yang disusun secara kumulatif yang artinya kedua sanksi pidana tersebut digabung menjadi satu sanksi terhadap suatu delik yang dalam praktek penjatuhan pidana terhadap terdakwa wajib dijatuhkan kedua-duanya. Tidak hanya pengaturan sanksi pidana secara kumulatif, bahkan semangat pemberantasan narkotika di Indonesia dengan mempertimbangkan dampaknya yang sangat besar, berpengaruh pada pembentukan undang-undang yang mengatur sanksi pidana secara kumulatif dengan pembatasan minimum khusus.

Memperhatikan bentuk sanksi pidana secara kumulatif dengan minimum khusus tersebut, pengadilan dalam hal ini hakim sebagai muaranya suatu proses peradilan dengan putusannya, pastinya dalam menjatuhkan pidana terhadap terdakwa harus didasarkan pada minimal 2 (dua) alat bukti yang sah, yang mana dari alat bukti tersebut hakim memperoleh keyakinan bahwa suatu tindak pidana benar-benar terjadi dan terdakwalah yang terbukti bersalah melakukakannya. Ketentuan tersebut sebagaimana Pasal 183 KUHAP.

Selain berpedoman pada Pasal 183 KUHAP, seorang hakim dalam menjatuhkan suatu putusan tentunya memperhatikan pula ketentuan dalam Undang-Undang Nomor 48 Tahun 2009 tentang Kekuasaan Kehakiman sebagaimana Pasal 50 ayat (1) mengatur bahwa putusan pengadilan selain memuat alasan dan dasar putusan juga memuat pasal tertentu dari peraturan perundang-undangan yang bersangkutan atau dasar tak tertulis yang dijadikan dasar untuk mengadili. ${ }^{8}$

Dalam prakteknya pertimbangan hakim dalam memutus suatu tindak pidana narkotika, pada dasarnya sama dengan pertimbangan hakim dalam memutus perkara tindak pidana lainnya, seperti halnya pertimbangan mengenai alasan pengapusan pertanggungjawaban pidana (baik alasan pembenar dan pemaaf), maupun hal yang memberatkan dan meringankan bagi terdakwa, selanjutnya dimusyawarahkan antara majelis hakim sebelum akhirnya dituangkan dalam suatu putusan.

Pertimbangan hakim dalam memutus perkara pidana selain terkait pembuktian unsur-unsur pasal yang didakwakan, selanjutnya akan bermuara pada proses musyawarah antar majelis untuk menjatuhkan pidana terhadap terdakwa. Proses inilah yang cukup menarik perhatian khususnya perkara tindak pidana narkotika, karena beberapa pasal dalam Undang-Undang Nomor 35

\footnotetext{
8 Pasal 50 ayat (1) Undang-Undang Nomor 48 Tahun 2009 tentang Kekuasaan Kehakiman.
} 
Tahun 2009 tentang Narkotika mengatur sanksi pidana pokok yang bersifat kumulatif bahkan terdapat ketentuan minimum khusus baik pidana penjara maupun denda. Adanya pengaturan sanksi pidana dalam Undang-Undang Nomor 35 Tahun 2009 tentang Narkotika yang mewajibkan untuk menjatuhkan pidana secara kumulatif dan terdapatnya ketentuan minimum khusus, utamanya terkait pidana denda, maka hal tersebut akan berimplikasi pada penerapan dan pelaksanaan putusannya, meskipun dalam Pasal 148 terdapat ketentuan mengenai pidana penjara sebagai pengganti pidana denda, apabila terpidana tidak mampu membayar. Sehingga suatu putusan hakim mengenai denda tersebut harus dipertimbangkan secara mendalam dengan memperhatikan segala aspek yang ada pada diri seorang terdakwa.

Diantara pasal dalam Undang-Undang Nomor 35 Tahun 2009 tentang Narkotika yang mengatur sanksi pidana berbentuk kumulatif dengan pembatasan minimum khusus dan dalam praktiknya banyak terjadi kasusnya di daerah hukum Pengadilan Negeri Mungkid (Kabupaten Magelang) adalah Pasal 112 ayat (1) yang sanksi pidananya berupa pidana penjara paling singkat 4 tahun dan paling lama 12 tahun dan pidana denda paling sedikit Rp. 800.000.000,00 dan paling banyak Rp. 8.000.000.000,00. Selain itu juga tindak pidana narkotika sebagaimana Pasal 114 ayat (1) yang sanksi pidananya penjara paling singkat 5 tahun dan paling lama 20 tahun dan pidana denda paling sedikit Rp. 1.000.000.000,00 dan paling banyak Rp. 10.000.000.000,00.

Perkara tindak pidana narkotika di daerah hukum Pengadilan Negeri Mungkid dapat dikatakan cukup banyak setiap tahunnya. Beberapa perkara tindak pidana narkotika yang dilimpahkan ke pengadilan terdiri atas kasus dengan unsur delik yang berbeda-beda dengan pasal dakwaan yang bervariatif pula. Sebagai contoh dakwaan yang diajukan terhadap seorang terdakwa melanggar Pasal 112 ayat (1) Undang-Undang Nomor 25 Tahun 2009 tentang Narkotika Subsidiair Pasal 127 ayat (1) huruf a Undang-Undang Nomor 25 Tahun 2009 tentang Narkotika, selanjutnya berdasarkan fakta hukum didepan persidangan berdasarkan alat bukti yang sah, perbuatan terdakwa tersebut terbukti sebagai penyalahguna sebagaimana Pasal 127 ayat (1) huruf a UndangUndang Nomor 25 Tahun 2009 dengan putusan berupa penjatuhan pidana penjara saja, oleh karena sanksi pidana denda tidak diatur dalam Pasal 127.

Beberapa putusan yang menjatuhkan pidana secara kumultaif antara pidana penjara dan denda dalam perkara tindak pidana narkotika melanggar Pasal 112 ayat (1) Undang-Undang Nomor 35 Tahun 2009 tentang Narkotika dan Pasal 114 ayat (1) Undang-Undang Nomor 35 Tahun 2009 tentang Narkotika di daerah 
hukum Pengadilan Negeri Kabupaten Magelang pada 2017 sampai dengan 2019 dapat dilihat pada tabel berikut ini:

Tabel 1.

Putusan perkara tindak pidana narkotika pada 2017 di Pengadilan Negeri Mungkid

\begin{tabular}{|c|c|c|c|c|}
\hline \multirow[b]{2}{*}{ No. } & \multirow[b]{2}{*}{ Nomor Putusan } & \multicolumn{3}{|c|}{ Putusan } \\
\hline & & Penjara & Denda (Rp) & $\begin{array}{l}\text { Penjara } \\
\text { pengganti } \\
\text { denda }\end{array}$ \\
\hline 1. & 14/Pid.Sus/2017/PN.Mkd & 4 tahun & 800.000 .000 & 2 bulan \\
\hline 2. & 76/Pid.Sus/2017/PN.Mkd & 4 tahun dan 6 bulan & 800.000 .000 & 4 bulan \\
\hline 3. & 77/Pid.Sus/2017/PN.Mkd & 4 tahun dan 6 bulan & 800.000 .000 & 4 bulan \\
\hline 4. & 218/Pid.Sus/2017/PN.Mkd & 5 tahun & 1.000.000.000 & 1 bulan \\
\hline 5. & 243/Pid.Sus/2017/PN.Mkd & 4 tahun & 800.000 .000 & 1 bulan \\
\hline
\end{tabular}

Sumber : Pengadilan Negeri Mungkid

Berdasarkan tabel 1 di atas, dapat disimpulkan bahwa penerapan pidana denda dalam putusan perkara tindak pidana narkotika dijatuhkan sesuai ancaman minimum yang diatur baik dalam Pasal 112 ayat (1) yang menentukan paling sedikit Rp800.000.000,00 (delapan ra

tus juta rupiah) maupun Pasal 114 ayat (1) yang menentukan paling sedikit Rp1.000.000.000,00 (satu miliar rupiah). Penjatuhan pidana denda oleh hakim dalam putusannya tersebut sebanding dengan tuntutan penuntut umum dalam tuntutannya sebagaimana tabel berikut:

Tabel 2.

Tuntutan perkara tindak pidana narkotika pada 2017 di Kejari Kabupaten Magelang

\begin{tabular}{lllrl}
\hline & & \multicolumn{2}{c}{ Tuntutan Penuntut Umum } \\
\cline { 3 - 5 } No. & Nomor Putusan & \multicolumn{1}{c}{ Penjara } & $\begin{array}{c}\text { Denda } \\
\text { (Rp) }\end{array}$ & $\begin{array}{c}\text { Penjara } \\
\text { pengganti } \\
\text { denda }\end{array}$ \\
\hline 1. & 14/Pid.Sus/2017/PN.Mkd & 5 tahun & 800.000 .000 & 4 bulan \\
2. & 76/Pid.Sus/2017/PN.Mkd & 2 tahun 6 bulan & -- & - \\
3. & 77/Pid.Sus/2017/PN.Mkd & 2 tahun 6 bulan & -- \\
4. & 218/Pid.Sus/2017/PN.Mkd & 6 tahun dan 6 bulan & 1.000 .000 .000 & 2 bulan \\
5. & 243/Pid.Sus/2017/PN.Mkd & 4 tahun dan 6 bulan & 800.000 .000 & 1 bulan \\
\hline
\end{tabular}
Sumber : Kejari Kabupaten Magelang

Berdasarkan tabel 1 dihubungkan dengan tabel 2 di atas, kecuali dalam poin 2 dan 3 pada masing-masing tabel yang terdapat perbedaan pasal yang terbukti antara tuntutan dengan putusan, yang mana hakim tidak sependapat dengan pasal yang dibuktikan penuntut umum atas perbuatan terdakwa, maka dapat 
disimpulkan adanya kecenderungan hakim senantiasa sependapat dengan tuntutan penuntut umum dalam penjatuhan sanksi pidana, meskipun penjatuhan pidana penjara pengganti denda mengalami kenaikan dan pengurangan dari tuntutan yang diajukan penuntut umum. Kecenderungan yang sama terjadi pada 2018 sebagaimana terlihat dalam tabel sebagai berikut:

Tabel 3.

Putusan perkara tindak pidana narkotika pada 2018 di Pengadilan Negeri Mungkid

\begin{tabular}{lllrl}
\hline & & \multicolumn{3}{c}{ Putusan } \\
\cline { 3 - 5 } No. & \multicolumn{1}{c}{ Nomor Putusan } & Penjara & $\begin{array}{c}\text { Denda } \\
\text { (Rp) }\end{array}$ & $\begin{array}{c}\text { Penjara } \\
\text { pengganti } \\
\text { denda }\end{array}$ \\
\hline 1. & 54/Pid.Sus/2018/PN.Mkd & 5 tahun & 1.000 .000 .000 & 3 bulan \\
2. & 74/Pid.Sus/2018/PN.Mkd & 7 tahun & 1.000 .000 .000 & 2 bulan \\
3. & 155/Pid.Sus/2018/PN.Mkd & 5 tahun & 1.000 .000 .000 & 1 bulan \\
4. & 169/Pid.Sus/2018/PN.Mkd & 4 tahun & 800.000 .000 & 2 bulan \\
5. & 181/Pid.Sus/2018/PN.Mkd & 6 tahun & 800.000 .000 & 2 bulan \\
6. & 222/Pid.Sus/2018/PN.Mkd & 5 tahun & 1.000 .000 .000 & 2 bulan \\
\hline
\end{tabular}

Sumber : Pengadilan Negeri Mungkid

Beberapa putusan pada 2018 sebagaimana dalam tabel 3 di atas, hampir sebanding dengan tuntutan yang diajukan oleh Penuntut Umum dalam surat tuntutannya sebagaimana tabel berikut:

Tabel 4.

Tuntutan perkara tindak pidana narkotika pada 2018 di Kejari Kabupaten Magelang

\begin{tabular}{rrrrr}
\hline & & \multicolumn{2}{c}{ Tuntutan Penuntut Umum } \\
\cline { 3 - 5 } No. & Nomor Putusan & Penjara & $\begin{array}{c}\text { Denda } \\
\text { (Rp) }\end{array}$ & $\begin{array}{c}\text { Penjara } \\
\text { pengganti } \\
\text { denda }\end{array}$ \\
\hline 1. 54/Pid.Sus/2018/PN.Mkd & 6 tahun & 1.000 .000 .000 & 3 bulan \\
2. 74/Pid.Sus/2018/PN.Mkd & 8 tahun & 1.000 .000 .000 & 5 bulan \\
3. 155/Pid.Sus/2018/PN.Mkd & 8 tahun & 1.000 .000 .000 & 1 bulan \\
4. 169/Pid.Sus/2018/PN.Mkd & 5 tahun & 800.000 .000 & 2 bulan \\
5. 181/Pid.Sus/2018/PN.Mkd & 5 tahun & 800.000 .000 & 2 bulan \\
6. 222/Pid.Sus/2018/PN.Mkd & 6 tahun & 1.000 .000 .000 & 2 bulan \\
\hline Sumber : Kejari Kabupaten Magelang & & &
\end{tabular}

Untuk 2019, didominasi perkara penyalahgunaan narkotika sebagaimana Pasal 127 ayat (1) huruf a Undang-Undang Nomor 35 Tahun 2009 tentang Narkotika, meskipun terdapat juga beberapa putusan terhadap terdakwa yang dipidana sesuai Pasal 112 ayat (1) dan Pasal 114 ayat (1) yang dapat dilihat pada tabel sebagai berikut: 
Tabel 5.

Putusan perkara tindak pidana narkotika pada 2019 di Pengadilan Negeri Mungkid

\begin{tabular}{|c|c|c|c|c|}
\hline \multirow[b]{2}{*}{ No. } & \multirow[b]{2}{*}{ Nomor Putusan } & \multicolumn{3}{|c|}{ Putusan } \\
\hline & & Penjara & $\begin{array}{c}\text { Denda } \\
\text { (Rp) }\end{array}$ & $\begin{array}{c}\text { Penjara } \\
\text { penggant } \\
\text { denda }\end{array}$ \\
\hline 1. & 19/Pid.Sus/2019/PN.Mkd & 5 tahun & 1.000 .000 .000 & 3 bulan \\
\hline 2. & 103/Pid.Sus/2018/PN.Mkd & 7 tahun & 1.000 .000 .000 & 3 bulan \\
\hline 3. & 111/Pid.Sus/2018/PN.Mkd & 4 tahun & 800.000 .000 & 2 bulan \\
\hline 4. & 192/Pid.Sus/2018/PN.Mkd & 6 tahun dan 4 bulan & 1.000.000.000 & 6 bulan \\
\hline 5. & 248/Pid.Sus/2018/PN.Mkd & 5 tahun & 1.000 .000 .000 & 2 bulan \\
\hline 6. & 247/Pid.Sus/2018/PN.Mkd & 4 tahun & 800.000 .000 & 3 bulan \\
\hline
\end{tabular}

Sumber : Kejari Kabupaten Magelang

Putusan pengadilan pada tabel $5 \mathrm{di}$ atas merupakan putusan terhadap terdakwa yang terbukti melakukan tindak pidana narkotika sebagaimana Pasal 112 ayat (1) dan Pasal 114 ayat (1) Undang-Undang Nomor 35 Tahun 2009 tentang Narkotika. Terkait besaran nilai putusan pidana denda yang telah dijatuhkan dalam putusan tersebut, hampir sebanding dengan yang dituntutkan oleh penuntut umum sebagaimana dapat dilihat pada tabel berikut:

Tabel 6.

Tuntutan perkara tindak pidana narkotika pada 2019 di Kejaksaan Negeri Kabupaten Magelang

\begin{tabular}{lllrl}
\hline & & \multicolumn{2}{c}{ Tuntutan Penuntut Umum } \\
\cline { 3 - 5 } No. & Nomor Putusan & \multicolumn{1}{c}{ Penjara } & \multicolumn{1}{c}{$\begin{array}{c}\text { Denda } \\
\text { (Rp) }\end{array}$} & $\begin{array}{c}\text { Penjara } \\
\text { pengganti } \\
\text { denda }\end{array}$ \\
\hline 1. & 19/Pid.Sus/2019/PN.Mkd & 6 tahun dan 6 bulan & 1.000 .000 .000 & 3 bulan \\
2. & $103 /$ Pid.Sus/2018/PN.Mkd & 8 tahun & 1.000 .000 .000 & 3 bulan \\
3. & $111 /$ Pid.Sus/2018/PN.Mkd & 4 tahun dan 6 bulan & 800.000 .000 & 2 bulan \\
4. & $192 /$ Pid.Sus/2018/PN.Mkd & 6 tahun dan 6 bulan & 1.000 .000 .000 & 6 bulan \\
5. & 248/Pid.Sus/2018/PN.Mkd & 6 tahun & 1.000 .000 .000 & 3 bulan \\
6. & 247/Pid.Sus/2018/PN.Mkd & 4 tahun dan 10 bulan & 800.000 .000 & 3 bulan \\
\hline
\end{tabular}
Sumber : Kejari Kabupaten Magelang

Berdasarkan dari tabel 1, tabel 3 dan tabel 5 di atas, dalam prakteknya di Pengadilan Negeri Kabupaten Magelang mengenai penjatuhan pidana terhadap terdakwa khususnya terkait pidana denda tergolong cukup tinggi. Apabila dihubungkan dengan rumusan Pasal 112 ayat (1) dan Pasal 114 ayat (1) UndangUndang Nomor 35 Tahun 2009 tentang Narkotika, dapat dilihat bahwa meskipun tuntutan pidana denda yang diajukan oleh penuntut umum, kemudian diputus 
oleh hakim cukup tinggi, akan tetapi semuanya masih on the track dengan ketentuan minimum khusus yang diatur dalam Pasal 112 ayat (1) yaitu sebesar Rp. 800.000.000,00, sedangkan dalam Pasal 112 ayat (1) ditentukan sebesar Rp. 1.000.000.000,00. Mengacu pada Pasal 148 Undang-Undang Nomor 35 Tahun 2009 tentang Narkotika yang berbunyi:

Apabila putusan pidana denda sebagaimana diatur dalam Undang-Undang ini tidak dapat dibayar oleh pelaku tindak pidana Narkotika dan tindak pidana Prekursor Narkotika, pelaku dijatuhi pidana penjara paling lama 2 (dua) tahun sebagai pengganti pidana denda yang tidak dapat dibayar.

Dihubungkan putusan pidana denda yang diuraikan pada tabel 1, tabel 3 dan tabel 5 di atas, maka pidana penjara pengganti denda yang dijatuhkan tergolong ringan yaitu berkisar antara 1 bulan hingga 6 bulan atau dapat disimpulkan dari putusan-putusan terkait pidana penjara pengganti denda tersebut tidak ada yang diatas 1 tahun, meskipun Pasal 148 sendiri mengatur bahwa pidana penjara pengganti denda yang tidak dibayarkan dapat dijatuhkan hingga paling lama 2 tahun.

Melihat putusan-putusan dalam tabel diatas terkait pidana denda dan pidana penjara pengganti denda, apabila dihubungkan antara kedua pidana yang dijatuhkan tersebut, maka dapat disimpulkan bahwa hakim sebenarnya menyadari pidana denda yang dijatuhkan dalam putusannya akan sulit untuk dibayarkan, bahkan tidak akan dibayar oleh terdakwa, terlebih para terdakwa sendiri rata-rata merupakan masyarakat dengan latar belakang tidak mampu secara finansial. Sehingga penerapan pidana denda dan pidana penjara pengganti denda yang dijatuhkan kepada terdakwa dapat dikatakan tidak rasional, karena pidana denda yang dijatuhkan nilainya cukup tinggi sedangkan pidana penjara pengganti denda hanya dalam hitungan bulan yang relatif singkat. Apabila dalam melihat putusan tersebut hanya terbatas pada amarnya saja, maka akan menilai adanya ketidakseimbang diantara pidana denda dan penjara pengganti denda yang terkesan singkat. Namun demikian dengan adanya putusan-putusan pidana denda dan penjara pengganti denda seperti tersebut diatas, tentunya hakim mempunyai dasar pertimbangan dalam rangka menentukan besaran pidana denda maupun penjara pengganti denda. Sehubungan dengan permasalahan ini, penulis menganalisa bahwa dasar hakim dalam menjatuhkan putusan pidana denda dan penjara pengganti denda dalam tindak pidana narkotika tidak dari dilepaskan dari 2 (dua) hal. Yang pertama, penafsiran hakim terkait pidana denda yang bersifat kumulatif-minimum khusus. Yang kedua, penilaian hakim terhadap keadaan sosial ekonomi pelaku delik Narkotika. Kedua hal tersebut selalu melekat bagi hakim dalam rangka menjatuhkan pidana dalam tindak pidana 
narkotika, utamanya terhadap dakwaan yang pasalnya mengatur sanksi pidana secara kumulatif dengan batasan minimum khusus.

\section{Penafsiran Hakim Mengenai Bentuk Pidana Denda yang Bersifat Kumulatif- Minimum Khusus}

Beberapa pasal dalam Undang-Undang Nomor 35 Tahun 2009 tentang Narkotika mengatur sanksi pidana secara kumulatif-minimum khusus. Penerapan sanksi pidana secara kumulatif-minimum khusus diantaranya diatur dalam Pasal 111 sampai dengan Pasal 126 yang besaran minimum pidana yang ditentukan masing-masing pasal bervariasi baik mengenai penjara maupun denda. Rumusan sanksi pidana dalam masing-masing pasal tersebut menggunakan frase kata "dan" yang artinya mewajibkan penjatuhan pidana secara bersama-sama antara penjara dan denda atau secara kumulasi. Sehingga jika terdakwa terbukti bersalah maka konsekuensi pidananya dijatuhi penjara dan denda.

Bentuk kumulatif sanksi pidana sebagaimana ditunjukkan dengan kata "dan" di sini tidak dapat disimpangi dengan menjatuhkan salah satu bentuk pidana misalnya penjara atau denda saja. Tidak dijatuhkannya kedua jenis pidana tersebut padahal telah nyata ketentuan pidana secara tegas menyatakan adanya kata "dan" mengakibatkan putusan dibatalkan, demikian Yurisprudensi MARI No. 13k/MIL/2001, yang mengemukakan:

bahwa oleh karena Mahkamah Tinggi Militer I Medan tidak menjatuhkan hukuman denda terhadap terdakwa, sedangkan hukuman dalam perkara Psikotropika bersifat kumulatif, maka Putusan Mahkamah Militer Tinggi I Medan harus dibatalkan. ${ }^{9}$

Kesimpulan dari putusan tersebut sangat jelas bahwa sifat kumulatif pengaturan suatu sanksi pidana tidak dapat disimpangi artinya wajib diterapkan oleh hakim dalam putusannya.

Berkaitan dengan sistem pidana minimum khusus, dikalangan para praktisi sendiri pendapatnya terpecah menjadi dua golongan di mana di satu sisi berpendapat jika sudah nyata tertulis pidana minimum khusus, maka demi kepastian hukum tidak boleh disimpangi karena pidana minimum khusus sudah merupakan kehendak pembentuk undang-undang dan merupakan manifestasi kehendak rakyat. Di pihak lain ada sebagian yang berpendapat meskipun pidana minimum khusus telah dirumuskan dalam suatu ketentuan undang-undang, namun hakim tidak terikat dengan adanya ketentuan tersebut dan dapat menjatuhkan pidana lebih rendah dari pidana minimum khusus yang ditentukan

9 A.R. Sujono dan Bony Daniel, Komentar dan Pembahasan UU Nomor 35 Tabun 2009 tentang Narkotika, Sinar Grafika, Jakarta, 2013, hlm. 240. 
karena putusan hakim haruslah pula didasarkan rasa keadilan disamping hakim bukanlah corong dari undang-undang semata. ${ }^{10}$

Berdasarkan hasil wawancara penulis dengan hakim pada Pengadilan Negeri Mungkid diperoleh kesimpulan bahwa didalam menjatuhkan putusan pidana denda dalam tindak pidana narkotika, utamanya yang ancaman pidananya bersifat kumulatif antara penjara dan denda dan yang paling banyak dilimpahkan ke pengadilan yaitu dengan dakwaan Pasal 112 ayat (1) atau Pasal 114 ayat (1) Undang-Undang Nomor 35 Tahun 2009 tentang Narkotika, hakim tetap memperhatikan ketentuan pidana yang diatur secara kumulatif dengan ketentuan minimum khusus dari kedua pasal tersebut. Artinya hakim dalam menerapkan pidana tetap berpedoman sesuai bentuk sanksi pidana yang diatur dalam kedua pasal tersebut yaitu kumulatif dan hakim akan menjatuhkan kedua sanksi pidana penjara dan denda sekaligus. Hal tersebut berpengaruh pula terhadap hakim dalam mempertimbangkan lamanya pidana penjara yang akan dijatuhkan, begitu pula dengan nilai besaran pidana denda dan penjara pengganti denda. Mengenai penentuan besaran pidana denda tidak terdapat pedoman atau parameter khusus bagi para hakim, pertimbangan tersebut dikembalikan kepada masingmasing hakim dengan melihat fakta hukum dipersidangan dari tujuan perbuatan dilakukan maupun jumlah barang (narkotika) dari tindak pidana tersebut. Dalam prakteknya terlihat hakim tetap menerapkan sanksi pidana sesuai bentuknya (kumulatif-minimum khusus), dan mengenai denda dalam penerapanya hakim lebih condong untuk mempertimbangkan lamanya penjara pengganti denda dalam menyikapi batasan minimum khusus denda yang cukup tinggi.

Mahkamah Agung Republik Indonesia sendiri telah mengeluarkan Surat Edaran Nomor 3 Tahun 2003, yang meminta para hakim memperhatikan dengan sungguh-sungguh penanganan perkara yang antara lain narkotika. Selanjutnya, dalam musyawarah Kerja Nasional Mahkamah Agung RI dengan Jajaran Pengadilan Tingkat Banding dari empat Lingkungan Peradilan Seluruh Indonesia di Palembang tahun 2009, pada sesi pembahasan pemecahan Masalah Hukum dalam praktik di PN/PT Bidang Pidana Khusus berkaitan dengan permasalahan pidana minimum khusus apakah hakim terkait secara mutlak dengan ancaman minimal (keadilan legalis) dalam penjatuhan putusan sedangkan rasa keadilan terlalu berat? Berpendapat pada prinsipnya tidak dapat, tetapi dalam hal-hal yang bersifat eksepsional bisa diterapkan. Pendapat yang sama juga berlaku terhadap penjatuhan putusan percobaan atas pasal-pasal yang mencantumkan ancaman minimal tersebut. ${ }^{11}$

${ }^{10}$ Ibid., hlm. 221.

11 Ibid., hlm. 222. 
Selain Surat Edaran Nomor 3 Tahun 2003 tersebut, dalam perkembanganya terkait system pidana minimum khusus terdapat pedoman bagi hakim sebagaimana Surat Edaran Ketua Mahkamah Agung RI. (SEMA) Nomor 03 Tahun 2015, yang didalamnya memuat rumusan hukum antara lain Kamar Pidana terkait Narkotika, memberikan pedoman sebagai berikut:

Hakim memeriksa dan memutus perkara harus didasarkan kepada Surat Dakwaan Jaksa Penuntut Umum (Pasal 182 ayat 3, dan 4 KUHAP). Jaksa mendakwa dengan Pasal 111 atau Pasal 112 Undang-Undang Nomor 25 Tahun 2009 tentang Narkotika, namun berdasarkan fakta hukum yang terungkap dipersidangan terbukti Pasal 127 Undang-Undang Nomor 25 Tahun 2009 tentang Narkotika yang mana pasal ini tidak didakwakan, Terdakwa terbukti pemakai dan jumlahnya relatif kecil (SEMA Nomor 4 Tahun 2010), maka Hakim memutus sesuai surat dakwaan tetapi dapat menyimpangi ketentuan pidana minimum khusus dengan membuat pertimbangan yang cukup. ${ }^{12}$

Kesimpulan dari SEMA Nomor 3 Tahun 2015 diatas apabila terdapat suatu dakwaan Pasal 111 atau Pasal 112 Undang-Undang Nomor 25 Tahun 2009 tentang Narkotika, namun berdasarkan fakta hukum yang terungkap dipersidangan terbukti pemakai sebagaimana Pasal 127 Undang-Undang Nomor 25 Tahun 2009 tentang Narkotika didukung dengan barang terkait tindak pidana sedikit, meskipun Pasal 127 tersebut tidak didakwakan, maka hakim memutus sesuai surat dakwaan tetapi dapat menyimpangi ketentuan pidana minimum khusus dengan membuat pertimbangan yang cukup.

Berdasarkan hasil wawancara penulis dengan hakim pada Pengadilan Negeri Mungkid diperoleh kesimpulan terkait penerapan sanksi pidana kumulatif (penjara dan denda) dengan minimum khusus dalam tindak pidana narkotika dihubungkan pula dengan adanya SEMA Nomor 3 Tahun 2015 tersebut, maka ketentuan minimum khusus yang diatur dalam Undang-Undang Nomor 35 Tahun 2009 tentang Narkotika tidak dapat disimpangi, artinya SEMA Nomor 3 Tahun 2015 itu sendiri tidak serta merta mengikat para hakim untuk mengikuti dalam prakteknya, sepanjang hakim memiliki pandangan sendiri berdasarkan suatu dasar hukum yang jelas. Mengenai SEMA Nomor 3 Tahun $2015 \mathrm{itu}$ sendiri terdapat beberapa perbedaan pandangan dikalangan para hakim yang memaknainya yaitu sebagai berikut:

a. Pandangan dengan tetap menerapkan Pasal 112 dengan sanksi pidananya mengikuti strike (merujuk) pada ketentuan Pasal 112 tersebut;

12 SEMA Nomor 3 Tahun 2015 tentang Pemberlakuan Rumusan Hasil Rapat Pleno Kamar Mahkamah Agung Tahun 2015 Sebagai Pedoman Pelaksana Tugas Pengadilan. 
b. Pandangan yang mengikuti SEMA, yaitu dengan tetap menerapkan Pasal 112, namun penerapan sanksi pidananya mengikuti Pasal 127 yang tidak mengatur minimum khusus dan tetap disertai dengan pidana denda;

c. Menggunakan dakwaan diluar yang didakwakan, yaitu hakim menerapkan suatu pasal diluar yang telah didakwaan oleh Penuntut Umum atau tidak didakwakan oleh Penuntut Umum.

Dari rumusan sanksi pidana denda minimum khusus yang secara tegas diatur dalam Undang-Undang Nomor 35 Tahun 2009 tentang Narkotika dan implementasinya dalam proses peradilan, khususnya hakim dalam mempertimbangkan putusan pidana denda yang hendak dijatuhkan, lebih cenderung untuk tetap berpedoman sesuai dengan ketentuan dalam UndangUndang Nomor 35 Tahun 2009 tentang Narkotika yang mengatur sistem minimum khusus, namun demikian demi memenuhi rasa keadilan, lamanya pidana penjara pengganti denda apabila tidak dibayarkan, disesuaikan dengan kebijaksanaan hakim dalam melihat keadaan sosial ekonomi terdakwa.

\section{Penilaian Hakim terhadap Keadaan Sosial Ekonomi Terdakwa}

Seorang hakim wajib untuk menegakkan hukum dan keadilan tanpa memihak. Hakim dalam memberikan keadilan melalui suatu putusan harus melihat dan menelaah secara mendalam mengenai kebenaran suatu peristiwa yang diajukan kepadanya, selanjutnya memberikan penilaian terhadap peristiwa tersebut dihubungkan dengan kaidah hukum yang berlaku.

Penilaian yang dimaksud penulis dalam perkara tindak pidana narkotika ini berkaitan dengan cara pandang hakim dalam mempertimbangkan keadaan sosial ekonomi terdakwa dalam hal sebagai dasar bagi hakim untuk menjatuhkan pidana denda meskipun dalam prakteknya hakim dihadapkan pada kemungkinan untuk tidak dapat menyimpangi undang-undang yang mengatur pidana denda secara minimum khusus.

Dalam prakteknya terdapat beberapa kendala yang ditemui oleh hakim dalam membuat pertimbangan suatu putusan tindak pidana narkotika terkait penerapan pidana denda, oleh karena hakim selain mempertimbangkan faktor yuridis, tentunya juga harus mempertimbangkan pula faktor non yuridis. Sejalan dengan ketentuan Pasal 5 ayat (1) Undang-Undang Nomor 48 Tahun 2009 tentang Kekuasaan kehakiman yang menyatakan hakim wajib menggali, mengikuti, dan memahami nilai-nilai hukum dan rasa keadilan yang hidup dalam masyarakat, faktor non yuridis yang harus dipertimbangkan oleh hakim dalam menerapkan pidana denda adalah supaya putusan tersebut dapat memberikan efek jera, karena dampak bahaya dari tindak pidana narkotika yang dapat merusak kehidupan generasi penerus bangsa. Pertimbangan mengenai unsur non yuridis 
tersebut terlihat pada beberapa putusan Pengadilan Negeri Mungkid dalam rangka menerapkan pidana yang dilakukan oleh hakim tanpa menyimpang dari pertimbangan yuridis dari tindak pidana.

Untuk membahas pertimbangan yuridis dan non yuridis oleh hakim dalam suatu putusan, penulis mengambil sampel 2 Putusan Pengadilan Negeri Mungkid dalam tindak pidana narkotika yang diputus pada tahun 2019 yaitu Putusan Nomor 19/Pid.Sus/2019/PN Mkd atas nama (terdakwa) Supardjo alias Padi bin Noto Sudarmo. Majelis hakim berdasarkan pertimbangannya menjatuhkan putusan: (1) Menyatakan Terdakwa Supardjo alias Padi bin Noto Sudarmo terbukti secara sah dan meyakinkan bersalah melakukan tindak pidana "Tanpa Hak atau Melawan Hukum Menjual Narkotika Golongan I", (2) Menjatuhkan pidana kepada terdakwa oleh karena itu dengan pidana penjara selama 5 tahun dan pidana denda sebesar Rp. 1.000.000.000,00 dengan ketentuan jika denda tidak dibayar diganti dengan pidana penjara selama 3 bulan. Selanjutnya perkara Nomor 247/Pid.Sus/2019/PN Mkd atas nama (terdakwa) Endah Susilowati alias Poppy alias Mbok Geger binti Sanudin. Majelis hakim berdasarkan pertimbangannya menjatuhkan putusan: (1) Menyatakan Terdakwa Endah Susilowati alias Poppy alias Mbok Geger binti Sanudin terbukti secara sah dan meyakinkan bersalah melakukan tindak pidana "Bersama-sama secara tanpa hak atau melawan hukum memiliki, menyimpan, menguasai Narkotika Golongan I dalam bentuk tanaman", (2) Menjatuhkan pidana kepada terdakwa oleh karena itu dengan pidana penjara selama 4 (lima) tahun dan pidana denda sebesar Rp. 8000.000.000,00 dengan ketentuan jika denda tidak dibayar diganti dengan pidana penjara selama 3 bulan.

Melihat kedua putusan tersebut, dapat disimpulkan bahwa dalam menjatuhkan pidana hakim mempertimbangkan unsur yuridis dan non yuridis dari tindak pidana yang dilakukan oleh terdakwa, akan tetapi dari kedua putusan tersebut tidak terdapat pertimbangan hakim yang secara eksplisit mendasari pidana denda yang dijatuhkan terhadap terdakwa. Sehubungan dengan hal tersebut berdasarkan hasil wawancara penulis, diperoleh penjelasan bahwa dalam prakteknya memang hakim tidak secara eksplisit menguraikan pertimbangan terkait pidana denda yang akan dijatuhkan kepada terdakwa, akan tetapi hal tersebut bukan berarti hakim tidak memberikan pertimbangan atas besaran nilai pidana denda yang dijatuhkan tersebut. Dalam hal ini hakim tidak asal mempertimbangkan besaran pidana denda yang akan dijatuhkan, setidaknya melihat kemampuan sosial ekonomi terdakwa dari fakta yang terungkap dipersidangan, antara lain pengakuan terdakwa khususnya latar belakang 
kehidupan terdakwa, sehingga dapat terlihat maksud dan tujuan terdakwa melakukan perbuatannya yang akan terungkap pula keadaan ekonomi terdakwa, dihubungkan dengan jumlah barang terkait tindak pidana yang dilakukan terdakwa, selanjutnya hakim memperoleh suatu pertimbangan mengenai kepantasan pidana denda yang akan dijatuhkan. Namun hal tersebut kembali terbentur dengan adanya minimum khusus pidana denda yang diatur dalam Undang-Undang Nomor 35 Tahun 2009 tentang Narkotika khususnya Pasal 112 ayat (1) dan Pasal 114 ayat (1), sehingga hakim akan mempertimbangkan besaran pidana denda yang akan dijatuhkan sesuai minimum khusus dari kedua pasal tersebut dan penjara pengganti denda yang relatif singkat karena tidak ada batasan minimum umum dalam penerapan penjara penggangti denda (Vide Pasal 148).

Melihat beberapa putusan tindak pidana narkotika yang diputus oleh Pengadilan Negeri Mungkid baik pada 2017, 2018 dan 2019 di atas, nampak bahwa putusan pidana penjara pengganti denda rata-rata dijatuhkan dalam waktu yang relatif singkat paling singkat 1 bulan dan paling lama dari kurun waktu tersebut adalah 6 bulan, meskipun dalam Pasal 148 sendiri memberikan range pidana penjara pengganti denda yang tidak dapat dibayar sampai dengan (paling lama) 2 tahun. Hal tersebut selaras dengan image hakim yang menilai bahwa terdakwa akan sulit membayar pidana denda yang sangat tinggi, sedangkan disatu sisi terdakwa yang diajukan kedepan persidangan atau pelaku tindak pidana narkotika yang rata-rata disidangkan di Pengadilan Negeri Mungkid memiliki latar belakang pekerjaan atau keadaan ekonomi menengah kebawah atau bukan tergolong sebagai pengedar besar.

Hakim berpandangan bahwa meskipun pengaturan pidana denda sendiri dalam undang-undang diterapkan dengan pola minimum khusus yang cukup tinggi atau nilainya besar, dengan penjatuhan pidana penjara pengganti denda yang relatif singkat, maka terpidana dihadapkan pada pilihan untuk menjalani penjara pengganti denda, dan hal tersebut justru sebagai alternatif pidana yang dapat dijalani terdakwa sesuai pertimbangan hakim dalam menilai kemampuan terdakwa untuk membayar denda.

Berdasarkan pandangan tentang teori keadilan yang dikemukakan oleh John Rawls, maka berkaitan dengan pidana denda yang diterapkan dalam putusan tindak pidana narkotika oleh Hakim pada Pengadilan Negeri Mungkid dapat disimpulkan sudah sesuai, sebagaimana pandangannya bahwa setiap individu harus dalam keadaan "posisi asli" (original position) yaitu adalah suatu keadaan awal di mana manusia digambarkan kembali pada sifat-sifat alaminya. Sifat asli manusia adalah: mementingkan diri sendiri, egois, moralis. Bertitik tolak dari posisi asli, orang akan sampai pada suatu persetujuan bersama untuk 
mewujudkan prinsip-prinsip keadilan yaitu kebebasan yang sama yang sebesarbesarnya dan prinsip perbedaan. Prinsip perbedaan menyatakan bahwa perbedaan sosial dan ekonomi harus diukur agar memberikan manfaat yang paling besar bagi mereka yang paling kurang beruntung. Prinsip persamaan yang adil atas kesempatan yang dimaknai ketidaksamaan sosial ekonomi harus diatur sedemikian rupa sehingga membuka jembatan dan kedudukan sosial bagi semua yang ada di bawah kondisi persamaan kesempatan. ${ }^{13}$

Prinsip keadilan tersebut dapat dilihat dalam putusan-putusan tindak pidana narkotika yang dijatuhkan oleh Pengadilan Negeri Mungkid didukung dengan hasil wawancara kepada hakim, bahwa hakim dalam menerapkan atau menjatuhkan pidana denda dan penjara pengganti denda senantiasa mempertimbangkan keadilan dan kepastian hukum serta kemanfaatan, meskipun pada suatu sisi hakim terikat pada bentuk sanksi pidana yang diatur dalam ketentuan Undang-Undang Nomor 35 Tahun 2009 tentang Narkotika yaitu minimum khusus, dan disisi lain ketentuan pidana denda harus dijatuhkan oleh hakim kepada terdakwa yang besarannya sangat tinggi dan kurang rasional dibandingkan dengan rata-rata keadaan ekonomi terdakwa yang diajukan kepersidangan, hakim tetap berusaha melalui pertimbangannya untuk memberikan keadilan dengan menjatuhkan penjara pengganti denda yang relatif singkat dengan harapan supaya terdakwa tidak merasakan keadaan mereka yang lemah (ekonomi) berimbas pada pidana berat yang diterimanya atau anggapan bahwa golongan ekonomi kuat yang dapat menikmati hukum. Sebagaimana arti keadilan berasal dari kata dasar "Adil" yang dalam bahasa Arab mempunyai arti berada di tengah-tengah, jujur, lurus, dan tulus. Terminologis adil berarti sikap yang bebas dari diskriminasi, ketidak jujuran, sehingga orang yang adil adalah orang sesuai dengan standar hukum, baik hukum agama, hukum positif (hukum negara), serta hukum sosial (hukum adat) yang berlaku14. Dalam Al-Qur'an, kata adil juga disebut qisth (QS Al Hujurat 49: 9). Dengan demikian, orang yang adil selalu bersikap tidak memihak, sikap yang tidak memihak kecuali pada kebenaran, tidak berpihak karena persahabatan, kesetaraan ras, kebangsaan atau agama (kepercayaan). Keberpihakan karena faktor tidak didasarkan pada kebenaran dalam Al-Qur'an disebut sebagai keberpihakan yang tidak bermoral atau hanya mengikuti hawa nafsu dan dilarang keras (QS An-Nisa'4:135). Allah sangat jelas menegaskan bahwa kebencian terhadap suatu kelompok/

\footnotetext{
${ }^{13}$ Damanhuri Fattah," Teori Keadilan Menurut John Rawls," dalam http://103.88.229.8/index.php/TAPIs/article/viewFile/1589/1324, Akses 21 Juli 2020.

${ }^{14}$ https://id.wikipedia.org/wiki/Adil, diakses pada tanggal 18 Maret 2020
} 
golongan, atau individu, seharusnya tidak menjadi kekuatan pendorong untuk bertindak tidak adil (QS Al Maidah 5: 8).

\section{Penutup}

Dasar pertimbangan hakim dalam menjatuhkan putusan tindak pidana narkotika berdasarkan ketentuan Undang-Undang Nomor 35 Tahun 2009 tentang Narkotika yang mengatur sanksi pidana pokok dengan sistem kumulatifminimum khusus, utamanya mengenai pidana pokok denda, tidak dapat dilepaskan dari 2 faktor, yaitu berkaitan dengan penafsiran hakim terkait bentuk pengaturan sanksi pidana dan penilaian hakim terhadap latar belakang terdakwa yang salah satunya keadaan sosial ekonomi. Kedua faktor tersebut selalu melekat bagi hakim dalam rangka menjatuhkan pidana, disamping karena permasalahan keterbatasan Undang-Undang Nomor 35 Tahun 2009 tentang Narkotika yang tidak memberikan suatu pedoman lengkap dalam hal penghitungan besaran denda yang dapat dijatuhkan, terlebih sanksi pidana denda diatur secara minimum khusus dengan besaran minimum yang cukup tinggi yang kemungkinan kecil hakim menyimpanginya dan dirasa tidak sesuai dengan keadaan sosial-ekonomi masyarakat Indonesia khususnya di daerah hukum Pengadilan Negeri Mungkid yang rata-rata pelaku delik narkotika merupakan masyarakat golongan bawah, sehingga ketentuan Pasal 148 Undang-Undang Nomor 35 Tahun 2009 tentang Narkotika menjadikan pandangan alternatif bagi hakim sebagai dasar pertimbangan penjatuhan pidana denda yang bersifat minimum khusus dengan memperhatikan pula keadaan sosial-ekonomi terdakwa dihubungkan barang terkait tindak pidana, sehingga bermuara pada putusan pidana penjara sebagai pengganti denda dengan waktu lebih singkat yang dirasa lebih rasional dan berkeadilan.

Ketentuan minimum khusus pidana denda dalam Undang-Undang Nomor 35 Tahun 2009 tentang Narkotika perlu ditinjau kembali dengan pertimbangan tidak diaturnya minimum khusus, akan memberikan keleluasaan utamanya bagi hakim dalam menjatuhkan besaran pidana denda terhadap terdakwa sesuai fakta yang terungkap dipersidangan dengan tetap memperhatikan keseimbangan antara pidana denda dengan penjara pengganti denda yang dijatuhkan. Dengan demikian harapan kedepan mengenai penjatuhan pidana denda akan lebih efesien, selain denda tersebut dapat dibayar oleh terpidana karena kemampuannya, juga terdapat nilai keadilan dari putusan hakim karena menguntungkan terpidana sendiri maupun negara dalam rangka mengatasi kelebihan narapidana penghuni lembaga pemasyarakatan yang membutuhkan 
anggaran operasional cukup besar, yang disisi lain anggaran tersebut dapat dipergunakan untuk prioritas pembangunan yang lain.

\section{Daftar Pustaka}

\section{Buku}

Atmasasmita, Romli, Sistem Peradilan Pidana (Criminal Justice System) Perspektif Eksistensialisme Dan Abolisionalisme, Bina Cipta, Jakarta, 1996.

Makarao, Mohammad Taofik, Pembaharuan Hukum Pidana Indonesia, Cetakan Pertama, Kreasi Wacana, Yogyakarta, 2005.

Moeljatno, Kitab Undang-Undang Hukum Pidana, Cetakan Keduapuluh Tujuh, Bumi Aksara, Jakarta, 2008.

Nababan, Panda dan R. M. Suripto (Penyunting Diskusi Pemikir Hukum Indonesia), Menangkap Rasa Keadilan Masyarakat oleh Penegak Hukum, Cetakan I, Yayasan Keadilan, Jakarta, 1988.

Sujono, AR. dan Bony Daniel. Komentar dan Pembahasan Undang-Undang Nomor 35 Tahun 2009 tentang Narkotika. Sinas Grafika, Jakarta, 2013.

Waluyo, Bambang, Penelitian Hukum Dalam Praktek, Sinar Grafika, Jakarta, 1996.

\section{Internet}

Indra, Yogi, "Pengertian Sistem Peradilan Pidana Menurut Para Ahli Beserta Unsur-Unsurnya", https://www.academia.edu/36002666/PENGERTIAN SISTEM PERADILAN PIDANA MENURUT PARA AHLI BESERTA UNSUR-UNSURNYA, diakses tanggal 28 Februari 2020.

\section{Peraturan Perundang-Undangan}

Undang-Undang Republik Indonesia Nomor 48 Tahun 2009 Tentang Kekuasaan Kehakiman, Lembaran Negara Republik Indonesia Tahun 2009 Nomor 157.

Undang-Undang Republik Indonesia Nomor 35 Tahun 2009 Tentang Narkotika, Lembaran Negara Republik Indonesia Tahun 2009 Nomor 143.

SEMA Nomor 3 Tahun 2015 tentang Pemberlakuan Rumusan Hasil Rapat Pleno Kamar Mahkamah Agung Tahun 2015 Sebagai Pedoman Pelaksana Tugas Pengadilan.

Pedoman Jaksa Agung Nomor 3 Tahun 2019 tentang Tuntutan Pidana Perkara Tindak Pidana Umum. 